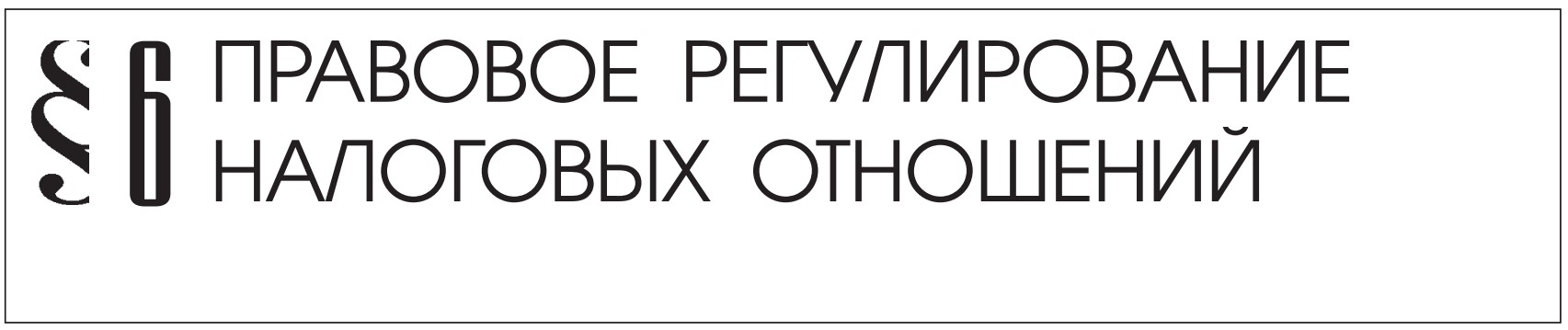

Барташевич C.B.

\title{
ЛЬГОТНЫЕ КАТЕГОРИИ ПЛАТЕЛЬЩИКОВ СТРАХОВЫХ ВЗНОСОВ В ГОСУДАРСТВЕННЫЕ ВНЕБЮДЖЕТНЫЕ ФОНДЫ: ПРОБЛЕМЫ ЗАКОНОДАТЕЛЬНОГО РЕГУЛИРОВАНИЯ И ПРАВОРЕАЛИЗАЦИИ
}

Аннотация: На сегодняшний день страховые взносы, пришедшие на смену единому социальному налогу, являются одним из наиболее ощутимых элементов формирования фискальной нагрузки на субъектов хозяйствования, в связи с чем особую актуальность приобретают вопросы снижения сумм платежей в государственные внебюджетные фонды, в т. ч. посредством приобретения права на применение льготного режима обложения страховыми взносами. Ранее плательщики льготных категорий не становились предметом отдельного научного интереса. Предлагаемое исследование охватывает возникающие на практике проблемы реализации льготного правового статуса плательщиками страховых взносов, выявляет способствующие их возникновению просчеты законодателя, включает в себя предложения и рекомендации по совершенствованию нормативно-правового регулирования в указанной сфере, способов обеспечения и защчиты прав и законных интересов льготных категорий плательщиков страховых взносов. При этом особое внимание автором уделяется проблеме подтверждениям права на льготное обложение страховыми взносами плательщциками, применяющими специальные налоговые режимы (УСН, ЕСХН, ЕНВД), а также лицами, использующими в своей деятельности труд инвалидов.

Review: Currently the insurance fees, which substituted for the unified social tax, comprise a considerable part of the fiscal burden for the economic subjects. Therefore the issues of lowering the sums of payments to the state non-budget funds, including the possibility to gain the right for the preferential application of insurance fees become topical. Earlier the preferential payers did not serve as objects of scientific interest. The study presented in this article is devoted to the practical problems of use of preferential legal status by the insurance fee payers and the shortcomings of the legislators, which caused these practical problems. The article also includes propositions and recommendations for the improvement of normative legal regulation in this spheres, as well as on the means for the protection of rights and lawful interests of the preferential insurance fee payers. Much attention is paid 


\section{Налоги и налогообложение - №7(109)• 2013}

by the author to the problem of validation of the right to preferential insurance fee taxation by the taxpayers using specialized tax regimes (Simplified Tax System, Single Agricultural Tax, Single Tax on Imputed Income), as well as the persons using the labor of disabled persons in their activities.

Ключевые слова: Страховой взнос, льготы, тариф, плательщзик, государственный внебюджетный фонд, оплата труда, организация, индивидуальньй предприниматель, единый социиальный налог, закон

Keywords: insurance fee, preference, tariff, payer, state non-budget fund, payment for labor, organization, individual entrepreneur, unified social tax, law.

еформа так называемого социального налогообложения в России, основной вехой которой стала отмена гл. 24 Налогового кодекса РФ (далее - НК РФ) ${ }^{1}$ и введение в действие Федерального закона «О страховых взносах в Пенсионный фонд РФ, Фонд социального страхования РФ, Федеральный фонд обязательного медицинского страхования» от 24.07.2009 №212-Ф3 (далее - Закон о страховых взносах), ${ }^{2}$ продолжается уже более 3-х лет. Однако практика применения законодательных новелл не только столкнулась с весьма существенными недостатками юридической техники, но также обнажила качественно новые пробелы и коллизии, прежде не характерные для налогового механизма уплаты взносов в государственные внебюджетные фонды.

Прежде всего, это касается вопросов установления и применения дифференцированных тарифов страховых взносов для отдельных категорий обязанных лиц. Согласно последним тенденциям правовых исследований наличие в сфере законодательного регулирования какихлибо юридических исключений (нормативных изъятий) определяет необходимость рассмотрения пониженных ставок страховых взносов в русле системы правового льготирования. ${ }^{3}$

${ }^{1}$ СЗ РФ. - 07.08.2000. - №32. - Ст. 3340.

${ }^{2}$ СЗ РФ. - 27.07.2009. - №30. - Ст. 3738.

${ }^{3}$ См. Морозова И. С. Теория правовых льгот: Автореф.
Иными словами, правовая природа пониженных тарифов страховых взносов позволяет квалифицировать их как разновидность правовых льгот, что с точки зрения правореализации выводит на первый план задачу оценки правомерности и обоснованности их применения в каждом конкретном случае.

В свою очередь, экономический смысл такого льготирования заключается в снижении фискальной нагрузки на обязанного субъекта с 34\% (в 2012-2015 гг. - с 30\%) до $27,1 \%$ и даже до $20 \%$ (ч. ч. 2, 3.4 ст. 58, ч. 1 ст. 58.2 Закона о страховых взносах). При этом не исключается возможность уменьшения облагаемой страховыми взносами базы отдельных выплат путем замены трудовых отношений на гражданско-правовые отношения выполнения работ (оказания услуг) и иных методов оптимизации, непосредственно не связанных с льготным правовым статусом плательщика. Дополнительная экономия в этом случае составит свыше 3\% (п. 2 ч. 3 ст. 9 Закона о страховых взносах с учетом ч. 1 ст. 5 Федерального закона от 24.07.1998 №125-Ф34). Таким образом, экономические преимущества отнесения плательщика к одной из льготных категорий очевидны,

дисс. ... докт. юрид. наук. Саратов: Саратовская государственная академия права, 2007. С. 10-13.

${ }^{4}$ СЗ РФ. - 03.08.1998. - №31. - Ст. 3803. 
т. к. могут превышать 13\% от суммы выплат и вознаграждений физическим лицам.

Важно при этом учитывать, что база для начисления страховых взносов, определяемая как сумма выплат и вознаграждений в пользу физических лиц, не является синонимом фонда оплаты труда (далее - ФОТ), и по своему правовому смыслу эти понятия не совпадают. ${ }^{5}$ В частности, из п. 86 Приказа Росстата от 24.10.2011 №435, определяющего состав фонда заработной платы, и ст. 255 НК РФ, определяющей состав расходов на оплату труда, видно, что в ФОТ входят не все выплаты и вознаграждения физическим лицам, а только некоторые из них, связанные с исполнением работниками своих трудовых обязанностей. Следовательно, база для начисления страховых взносов шире, чем ФОТ, за счет включения в нее вознаграждений по гражданско-правовым договорам и иных выплат в пользу физических лиц, застрахованных в соответствии с иными законами о конкретных видах обязательного социального страхования (ч. 1 ст. 8 Закона о страховых взносах).

Рассмотрим же некоторые наиболее распространенные льготные категории плательщиков страховых взносов и связанные с приобретением и подтверждением их правового статуса проблемы.

Положения ст. ст. 58, 58.1, 58.2 Закона о страховых взносах устанавливают льготы (путем предоставления права на применение пониженных тарифов страховых взносов) для отдельных категорий плательщиков при условии соблюдения ими определенных условий. При этом в качестве критериев наличия права на применение пониженного тарифа страховых

\footnotetext{
${ }^{5}$ См. Кроплис В. Ю. Некоторые правовые аспекты соотношения норм налогового и трудового законодательства при уплате единого социального налога // Арбитражные споры. - 2007. - № 4. С. 91.
}

взносов законодателем приняты, во-первых, вид выплат по признаку их получателя, а во-вторых, категория плательщика, обладающего тем или иным специальным правовым статусом.

Так, анализ п. 3 ч. 1 ст. 58 Закона о страховых взносах позволяет дифференцировать льготируемые категории плательщиков взносов по следующим группам:

- организации независимо от организационно-правовой формы и физические лица как зарегистрированные, так и не зарегистрированные в качестве индивидуальных предпринимателей, производящие выплаты и вознаграждения физическим лицам, являющимся инвалидами I, II или III группы;

- общественные организации инвалидов, т. е. организации, созданные инвалидами и лицами, представляющими их интересы, в целях защиты прав и законных интересов инвалидов, обеспечения им равных с другими гражданами возможностей, решения задач общественной интеграции инвалидов, среди членов которых инвалиды и их законные представители составляют не менее $80 \%$, а также союзы (ассоциации) указанных организаций (ч. 2 ст. 33 Федерального закона «О социальной защите инвалидов в РФ» от 24.11.1995 №181-Ф36);

- организации, уставный капитал которых полностью состоит из вкладов общественных организаций инвалидов и в которых среднесписочная численность инвалидов составляет не менее $50 \%$, а доля заработной платы инвалидов в ФОТ составляет не менее $25 \%$;

- учреждения, созданные для достижения образовательных, культурных, лечебно-оздоровительных, физкультурно-спортивных, научных, информационных и иных социальных целей, а также для оказания правовой и

${ }^{6}$ СЗ РФ. - 27.11.1995. - №48. - СТ. 4563. 


\section{Налоги и налогообложение - №7(109)• 2013}

иной помощи инвалидам, детям-инвалидам, их родителям или иным законным представителям, единственными собственниками имущества которых являются общественные организации инвалидов.

С юридико-технической точки зрения конструкция п. 3 ч. 1 ст. 58 Закона о страховых взносах представляется не вполне удачной. Последовательное недифференцированное перечисление льгот, в одном случае распространяющихся на выплаты отдельным лицам (инвалидам), а в другом - на лиц, осуществляющих такие выплаты, «перегружает» правовую норму, делает ее содержание сложным для восприятия и не позволяет однозначно установить - распространяется ли ограничение по субъектному составу получателей вознаграждений, обозначенное словосочетанием «в отношении указанных выплат и вознаграждений», на все или только на некоторые категории плательщиков из указанных в п. 3 ч. 1 ст. 58 Закона о страховых взносах.

Ответ на данный вопрос дается в Письмах Минздравсоцразвития РФ от 24.02.2010 №104/306089-197 и от 09.03.2010 №495-19, ${ }^{8}$ согласно которым организации, не являющиеся общественными организациями инвалидов, не имеющие в качестве единственных учредителей общественные организации инвалидов и не преследующие в качестве своей уставной деятельности цели оказания помощи инвалидам, тем не менее, вправе исчислять страховые взносы с выплат работникам-инвалидам I, II или III группы с применением пониженных тарифов.

В целях же совершенствования юридической техники законодательства о страховых взносах, повышения прозрачности, четкости и ясности используемых в нем формулировок представляется необходимым разделить перечисленные в п. 3 ч. 1 ст. 58 Закона о страховых взносах категории плательщиков посредством точки с запятой (взамен существующего перечисления через запятую) либо использовать конструкцию списка, подобную той, которая использовалась ранее в ст. 239 НК РФ.

Таким образом, только первая из вышеприведенных категорий плательщиков страховых взносов ограничена в праве применения пониженных тарифов субъектным составом получателей выплат и вознаграждений, т. е. льготируемыми для них являются только выплаты в пользу работников-инвалидов. Страховые взносы в отношении работников, не являющихся инвалидами, уплачиваются по общим ставкам, определенным ст. ст. 12, 58.2 Закона о страховых взносах. Все прочие льготы, перечисленные в п. 3 ч. 1 ст. 58 Закона о страховых взносах, распространяются в целом на плательщика, отвечающего признакам той или иной льготируемой категории, вследствие чего дают им право применять пониженные тарифы в отношении выплат любому работнику или исполнителю (подрядчику) по гражданско-правовому договору.

Третьей категории организаций, привлекающих труд инвалидов, нужно учитывать следующие нюансы. При решении вопроса о возможности применения льготных условий уплаты страховых взносов организация рассчитывает среднесписочную численность работающих инвалидов, руководствуясь Приказами Росстата от 20.07.2010 №2569 и от 12.11.2008 №278, ${ }^{10}$ согласно которым среднесписочная численность включает численность собственно работников, а также среднее за период количество внешних со-

\footnotetext{
${ }^{7}$ Нормативные акты для бухгалтера. - 2010. - №9.

${ }^{9}$ Вопросы статистики. - 2010. - №9.

${ }^{8}$ Нормативные акты для бухгалтера. - 2010. - №9.

${ }^{10}$ Вопросы статистики. - 2009. - №4. 
вместителей и лиц, выполнявших работы по договорам гражданско-правового характера. В то же время, в среднесписочную численность не входят работники-инвалиды, привлеченные из других организаций в рамках исполнения договоров об оказании услуг путем предоставления персонала. ${ }^{11}$

Как видно из раздела 1 формы П-4 и п. 79 Приказа Росстата от 12.11.2008 №278, периоды, по итогам которых рассчитывается среднесписочная численность разнятся и могут быть представлены отчетным месяцем (для организаций, не признаваемых субъектами малого предпринимательства, численность которых за предшествующий год более 15 человек) или отчетным кварталом (для субъектов малого предпринимательства, численность которых за предшествующий год не превышает 15 человек). Соответственно, в случае изменения (до уровня менее 25\%) численности работающих инвалидов момент прекращения права применять пониженные тарифы страховых взносов также будет разным для организаций, имеющих и не имеющих статус субъекта малого предпринимательства. Первые находятся в более выгодном положении, т. к. снижение в отдельно взятом месяце числа работников-инвалидов не дает повода говорить о каком-либо изменении среднесписочной численности вплоть до окончания квартала, и значит не влечет лишение права начислять взносы по льготным тарифам за данный месяц. Напротив, не относящиеся к субъектам малого предпринимательства организации при снижении в отдельном месяце среднего числа инвалидов до уровня менее $25 \%$ от общего числа работников влечет обязанность уплатить взносы за соответствующий месяц уже по общеустановленным тарифам.

\footnotetext{
${ }^{11}$ См. Постановление Второго арбитражного апелляционного суда от 28.04.2007 №A17-2293/2006.
}

Правовое положение четвертой из вышеуказанных льготных категорий организаций определяется ограничением круга их учредителей (общественные организации инвалидов), организационно-правовых форм (учреждения) и особыми уставными целями деятельности таких организаций (образование и наука, информационная и правовая помощь, организация лечебно-оздоровительных, физкультурно-спортивных и иных подобных мероприятий для инвалидов). При этом в практике арбитражных судов ${ }^{12}$ признание права на льготу, установленную для учреждений, созданных общественными организациями инвалидов, ставится в зависимость от подтверждения этого права учредительными документами (или реестром участников, членов), в которых должна содержаться запись о собственнике имущества и об уставных целях создания и деятельности юридического лица, а также от наделения данного учреждения достаточным для осуществления уставной деятельности имуществом и финансирования его учредителем, что проистекает из требований п. 1 ст. 120 ГК РФ, ${ }^{13}$ П. п. 1, 2 ст. 2, п. 1 ст. 9 Федерального закона «О некоммерческих организациях» от 12.01.1996 №7-Ф3. ${ }^{14}$

Кроме того, в настоящее время названная категория плательщиков не ограничена в использовании сэкономленных на уплате страховых взносов средств, при том что некоторые из работников, с выплат которым также не уплачиваются взносы, могут и не быть инвалидами. Представляется, что с целью избежания фактов уклонений от уплаты страховых

\footnotetext{
${ }^{12}$ См. Постановление ФАС Московского округа от 30.04.2008 №KA-А40/2825-08, Постановление ФАС Северо-Западного округа от 17.09.2007 №A56$15381 / 2006$

${ }^{13}$ СЗ РФ. - 05.12.1994. - №32. - Ст. 3301.

${ }^{14}$ СЗ РФ. - 15.01.1996. - №3. - Ст. 145.
} 
DOI: $10.7256 / 1812-8688.2013 .7 .9355$

При цитировании этой статьи сноска на dоі обязательна

\section{Налоги и налогообложение - №7(109)• 2013}

взносов возможность применения пониженных тарифов следует ограничить дополнительным условием - направлением полученной экономии (которая может достигать 13,8\% от ФОТ) исключительно на уставные цели, связанные с социальной, психологической и профессиональной адаптацией инвалидов, их реабилитацией, социальной и материальной поддержкой, удовлетворением иных потребностей инвалидов.

Среди субъектов, на которых распространяются пониженные тарифы, предусмотренные п. 3 ч. 1 ст. 58 Закона о страховых взносах, исключением являются плательщики, занимающиеся производством и (или) реализацией минерального сырья, подакцизных и иных товаров, включенных в перечень, утвержденный Постановлением Правительства РФ от 28.09.2009 №762. ${ }^{15}$ Это касается и операций в рамках посреднических договоров. ${ }^{16}$ Однако важно понимать, что утрата производителями и продавцами таких товаров права на применение пониженных тарифов касается лишь вознаграждений физических лиц, не являющихся инвалидами. В отношении выплат инвалидам указанные плательщики страховых взносов могут применять пониженные тарифы независимо от того, какие товары они производят и реализуют, что подтверждается Письмом Минздравсоцразвития РФ от 09.03.2010 №49519, хотя в теории дискуссии по данному вопросу продолжаются. ${ }^{17}$

По смыслу п. 3 ч. 1 ст. 58 во взаимосвязи с ч. 1 ст. 7 Закона о страховых взносах по понижен-

${ }^{15}$ С3 РФ. - 05.10.2009. - №40 (ч. 2). - Ст. 4699.

${ }^{16}$ См. Шилова Л. А. Если общественная организация инвалидов утратила право на льготу по ЕСН // Российский налоговый курьер. - 2009. - №12. С. 72.

${ }^{17}$ См. Кирилова О. Е. Страховые взносы: изменения и нерешенные вопросы // Налоговая политика и практика. - 2011. - №4. C. 52. ным тарифам облагаются не только выплаты инвалидам, работающим по трудовым договорам, но и вознаграждения, выплачиваемые инвалидам по гражданско-правовым договорам и договорам о создании, использовании и распоряжении объектами интеллектуальной собственности. В этой случае плательщик может дополнительно сэкономить как минимум 3,4\%, снизив свою финансовую нагрузку с 27,1\% до $23,7 \%$ за счет высвобождения из-под обложения сумм, подлежащих уплате в ФСС РФ, включая взносы на страхование от несчастных случаев на производстве и профессиональных заболеваний. Однако если организация строит свои отношения с работающими у нее инвалидами на основе гражданско-правовых договоров, в т. ч. договоров авторского заказа, она рискует утратить право на применение пониженных тарифов страховых взносов, ведь буквальное прочтение п. 3 ч. 1 ст. 58 Закона о страховых взносах обязывает для подтверждения права на льготу учитывать не суммарный объем выплат и вознаграждений физическим лицам, а долю выплат из ФОТ, куда в силу Приложения №1 к Приказу Росстата от 24.07.2012 №407 вознаграждения по договорам гражданско-правового характера не входят.

В схожем положении оказываются инвалиды I, II и III групп, зарегистрированные в качестве индивидуальных предпринимателей, самостоятельно обеспечивающие себя работой, и потому обязанные уплачивать взносы по общеустановленным ч. 1 ст. 14 Закона о страховых взносах тарифам. Между тем, данные лица лишены льготного режима обложения подобного тому, который существовал в системе ранее действовавшего правового регулирования (пп. 3 п. 1 ст. 239 НК РФ) и который в настоящее время распространяется только на юридических лиц, производящих выплаты и вознаграждения инвалидам. 
В результате и организации, производящие выплаты инвалидам по договорам гражданско-правового характера, и индивидуальные предприниматели - инвалиды, и главы крестьянских фермерских хозяйств инвалиды оказываются в неравном правовом и экономическом положении по сравнению с иными лицами, указанными в п. 3 ч. 1 ст. 58 Закона о страховых взносах. При этом объективных обстоятельств, оправдывающих необходимость установления различий в правовом регулировании, не усматривается (с той лишь разницей, что в отличие от организаций индивидуальные предприниматели фактически совмещают в себе статус плательщиков страховых взносов и лиц, в пользу которых эти взносы уплачиваются). По этой причине представляется крайне важным устранение не согласуемого с ч. 2 ст. 19 Конституции РФ $\Phi^{18}$ неравенства путем внесения в законодательство изменений, распространяющих п. 3 ч. 1 ст. 58 Закона о страховых взносах на индивидуальных предпринимателей - инвалидов I, II или III группы, а также организаций, в которых доля выплат и вознаграждений инвалидам в общем объеме выплат и вознаграждений физическим лицам составляет не менее $25 \%$. При этом целесообразно установить льготный режим обложения не только по отношению к взносам, уплачиваемым предпринимателями-инвалидами за себя, но также к взносам, подлежащим уплате за их наемных работников, что будет служить стимулированию самозанятости инвалидов, созданию ими собственных предприятий, увеличению объемов продукции (работ, услуг), произведенных инвалидами, и, в конечно счете, повышению финансовой защищенности представителей социально слабых слоев населения.

${ }^{18}$ СЗ РФ. - 26.01.2009. - №4. - Ст. 445.
Поскольку пониженные тарифы страховых взносов применяются в отношении выплат гражданам, являющимся инвалидами I, II или III группы, важно принимать во внимание связанные с этим хитросплетения норм законодательства о страховых взносах и законодательства о социальном обеспечении.

С учетом содержания таблицы 3.1 раздела I расчета по форме 4-ФСС и раздела 3 расчета по форме РCB-1, утвержденных Приказами Минтруда РФ от 19.03.2013 №107 $\mathrm{H}^{19}$ и от 28.12.2012 №639н ${ }^{20}$ соответственно, документальным основанием для применения пониженных тарифов страховых взносов является представление работником справки, подтверждающей факт установления инвалидности и выдаваемой учреждением медико-социальной экспертизы в порядке, установленном п. 36 Правил признания лица инвалидом, утвержденных Постановлением Правительства РФ от 20.02.2006 №95..$^{21}$ При этом данная справка, как видно из ее формы, утвержденной Приказом Минздравсоцразвития РФ от 24.11.2010 №1031н,22 предусматривает указание в ней в соответствии с п. 7 Правил признания лица инвалидом группы инвалидности или категории «ребенок-инвалид».

Однако, несмотря на то, что причины для признания инвалидами детей и взрослых одинаковы по своей сути, буквальное толкование п. 3 ч. 1 ст. 58 Закона о страховых взносах позволяет облагать страховыми взносами по пониженным тарифам исключительно вознаграждения лиц, которым присвоена одна из трех групп инвалидности. На выплаты несовершеннолетним работникам-инвалидам

\footnotetext{
19 Российская газета. - 13.06.2013. - №125.

${ }^{20}$ Российская газета. - 15.03.2013. - №56.

${ }^{21}$ С3 РФ. - 27.02.2006. - №9. - СТ. 1018.

22 Российская газета. - 28.01.2011. - №17.
} 
DOI: $10.7256 / 1812-8688.2013 .7 .9355$

При цитировании этой статьи сноска на dоі обязательна

\section{Налоги и налогообложение - №7(109)• 2013}

взносы начисляются по общеустановленным тарифам. Налицо вновь допущенное законодателем нарушение принципов равенства и справедливости, которое отнюдь не способствует увеличению числа рабочих мест для лиц, нуждающихся в повышенной социальной защите, обеспечению условий для их занятности и соответствующему стимулированию работодателей.

Обращает на себя внимание и тот факт, что при наличии льготных категорий плательщиков в действующем законодательстве о страховых взносах отсутствуют четко прописанные механизм и условия возникновения, прекращения и возобновления льготного правового статуса. Судебная практика применения законодательства о страховых взносах в этой части пока еще слабо выработана. Однако можно обратиться к общим условиям и правилам определения момента утраты права на применение налоговых льгот, ранее сложившимся в практике разрешения судами споров о доначислении единого социального налога (далее - ЕСН).

Так, утрата права на льготу связывалась с прекращением или возникновением обстоятельств, ввиду наличия или отсутствия которых эта льгота была предоставлена налогоплательщику. При этом суды отмечали, что обязанность уплаты налога в полном размере, т. е. без учета льготы, возникает с начала месяца, в котором было утрачено право на льготу. В свою очередь, момент возникновения права на льготу определяется началом месяца, когда плательщиком были соблюдены все установленные законом условия, дающие ему возможность приобрести право на соответствующую льготу. ${ }^{23}$ Аналогичная позиция высказывалась

${ }^{23}$ См. Постановление ФАС Уральского округа от 12.12.2007 №Ф09-10227/07-С2, Постановление ФАС Северо-Западного округа от 08.06.2007 №A5643894/2006. в Письме Минфина РФ от 05.04.2006 №0305-02-04/33 и Письме ФНС РФ от 25.03.2009 №ШС-22-3/221@, где были рассмотрены ситуации, когда общественные организации инвалидов лишались права на применение льготы по ЕСН, начиная с месяца, в котором происходило превышение установленного законом предельного численного состава организации и, наоборот, организации приобретали право на льготу с начала месяца, в котором их работнику была установлена инвалидность.

Таким образом, в качестве отправной точки для определения момента прекращения права на применение пониженных тарифов страховых взносов должно приниматься первое число месяца отчетного периода, в котором было нарушено хотя бы одно из условий применения льготного обложения. И наоборот, моментом возникновения (возобновления) права на применение пониженных тарифов будет являться первое число месяца, в течение которого плательщиком соблюдались все предусмотренные законом условия, в совокупности дающие право на уплату взносов по пониженным тарифам.

В частности, из положений п. п. 9, 10, 13 Правил признания лица инвалидом следует, что инвалидность устанавливается на определенный срок, который по смыслу п. п. 11, 12 этих Правил исчисляется со дня поступления от гражданина заявления о проведении медико-социальной экспертизы и до первого числа месяца, следующего за месяцем, на который назначено проведение очередной медико-социальной экспертизы (переосвидетельствования) этого гражданина. Следовательно, все правовые последствия, в т. ч. регламентированные законодательством о страховых сборах, признания лица инвалидом действуют в течение указанного периода. Иными словами, право организации или предпринимателя уплачивать взносы по пониженным тарифам 
возникает не в том месяце, когда работник фактически представил работодателю справку об инвалидности, а с первого числа месяца, в котором работник обратился с соответствующим заявлением в бюро медико-социальной экспертизы. Такая дата указывается как в самой справке, так и в выписке из акта освидетельствования. Если же с учетом времени, объективно необходимого для назначения и проведения медико-социальной экспертизы, дата установления инвалидности и дата представления справки приходятся на разные отчетные (или даже расчетные) периоды, то сумма страховых взносов за данного работника, перечисленная во внебюджетные фонды в предыдущие месяцы, подлежит перерасчету работодателем с внесением соответствующих изменений в отчетность.

Аналогичным образом право на применение пониженных тарифов в отношении выплат и вознаграждений инвалидам прекращается. Согласно п. п. 12, 39, 40 Правил признания лица инвалидом переосвидетельствование проводится в случаях истечения срока, на который устанавливалась инвалидность либо изменения состояния его здоровья. Переосвидетельствование инвалида может осуществляться заблаговременно, но не более чем за 2 месяца до истечения установленного срока инвалидности. Соответственно, в случае принятия решения об отказе в признании гражданина инвалидом и независимо от даты его принятия у работодателя возникает обязанность уплаты страховых взносов по общим тарифам с первого числа месяца, следующего за месяцем, в котором истек установленный срок инвалидности.

В свете изложенного следует решительно не согласиться с теми авторами, по мнению которых право на льготу возникает с начала месяца, в котором была представлена справка, подтверждающая факт инвалидности, ${ }^{24}$ a прекращается в месяце, когда работник не прошел переосвидетельствование и ему была снята инвалидность, ${ }^{25}$ поскольку это противоречит нормам как законодательства о страховых взносах, так и ранее действовавшего налогового законодательства.

Что касается иных льготируемых категорий плательщиков и оснований применения ими пониженных тарифов страховых взносов, моментом возникновения права на ту или иную преференцию, предусмотренную ч. 2 ст. 58 Закона о страховых взносах, следует считать первое число первого месяца отчетного (расчетного) периода, в котором организацией или индивидуальным предпринимателем была выполнена совокупность перечисленных в соответствующем пункте ч. 1 ст. 58 Закона о страховых взносах условий начала применения пониженных тарифов.

В свою очередь, при изменении в течение отчетного (расчетного) периода хотя бы одного из условий льготного обложения страховыми взносами (в т. ч. места, вида или показателей осуществляемой экономической деятельности, штатной численности, размера ФОТ, состава учредителей, режима налогообложения) плательщик утрачивает право на применение пониженных тарифов и обязан исчислять страховые взносы в общеустановленном порядке с первого дня того отчетного периода, когда прекратились или возникли обстоятельства, с наличием или отсутствием которых ч. 1 ст. 58 Закона о страховых взносах связывает право на льготу.

\footnotetext{
${ }^{24}$ См. Климова М. A. Единый социальный налог и взносы на обязательное пенсионное страхование // Экономикоправовой бюллетень. - 2008. - №11. С. 77.

${ }^{25}$ См. Нестеров C. E. Начисляем страховые взносы: разъясняют специалисты ФСС // Оплата труда: бухгалтерский учет и налогообложение. - 2012. - №2. С. 56; Петров A. В. Налоговая экономия: реальные решения / А. В. Петров. - М.: Бератор Паблишинг, 2009. С. 102.
} 


\section{Налоги и налогообложение - №7(109)• 2013}

Если же в текущем налоговом периоде организация вновь начинает соответствовать условиям, установленным в одном из пунктов ч. 1 ст. 58 Закона о страховых взносах, льгота к выплатам, начисленным в пользу каждого физического лица, начинает применяться (возобновляется) с первого дня первого месяца того отчетного периода, когда условия для применения льготы были восстановлены.

Для правильного решения вопроса о том, было ли плательщиком льготной категории утрачено право на применение пониженных тарифов страховых взносов, важно принимать во внимание следующие юридически и экономически значимые обстоятельства.

Так, на сегодняшний день в число льготируемых категорий входят плательщики страховых взносов, применяющие упрощенную систему налогообложения (далее - УСН). При этом положения ст. 58 и ст. 58.2 Закона о страховых взносов позволяют сгруппировать плательщиков единого налога в связи с применением УСН по двум взаимосвязанным показателям - виду осуществляемой экономической деятельности и размеру применяемых ими льготных ставок страховых взносов, а именно:

- организации и индивидуальные предприниматели, производящие выплаты и иные вознаграждения в пользу физических лиц и применяющие УСН вне всякой зависимости от вида их экономической деятельности, совокупный размер обложения взносами которых составляет 30\% (ч. 1 ст. 58.2 Закона о страховых взносах);

- организации и индивидуальные предприниматели, производящие выплаты и иные вознаграждения в пользу физических лиц, применяющие УСН и осуществляющие экономическую деятельность по видам, перечисленным в п. п. 8, 11 ч. 1 ст. 58 Закона о страховых взноcax, совокупный размер обложения взносами которых составляет 20\% (ч. 3.4 ст. 58 Закона о страховых взносах).

Исследовательский интерес с точки зрения правореализации льготных тарифов представляет последняя категория плательщиков страховых взносов. Вызвано это различием сроков, по истечении которых исчисляются и уплачиваются, с одной стороны, страховые взносы в виде ежемесячных обязательных платежей, а с другой, единый налог в виде поквартальных авансовых платежей.

Поскольку в силу п. 4 ст. 346.13 НК РФ налогоплательщик считается утратившим право на применение УСН с начала квартала, в котором показатели его деятельности перестали соответствовать обязательным требованиям гл. 26.2 НК РФ, постольку и право на применение пониженных тарифов страховых взносов следует считать прекращенным с первого дня того же квартала. Такое толкование, основанное на аналогии положений НК РФ, дается и в Письме Минздравсоцразвития РФ от 24.11.2011 №5004-19. ${ }^{26}$ При этом суммы страховых взносов, уплаченных с начала квартала, подлежат перерасчету и доплате в бюджет, исходя из общеустановленных тарифов. И здесь может возникнуть проблема: на практике органы государственных внебюджетных фондов со ссылкой на Письмо Минздравсоцразвития РФ от 15.09.2011 №3333-1927 нередко начисляют плательщику штрафы и пени на суммы страховых взносов, несвоевременно уплаченных в течение расчетного периода в связи с утратой им права на применение УСН. Такая ситуация не согласуется с принципами справедливости и виновной ответственности, поскольку доплата сумм страховых взносов за рамками сроков, установленных ч. 5 ст. 15 Закона о страховых

\footnotetext{
${ }^{26}$ Официальные документы. - 2011. - №46.

27 Официальные документы. - 2011. - №36.
} 
взносах, производится в связи с обстоятельствами, которые не могли быть обнаружены субъектом хозяйствования ранее, т. е. не по вине плательщика. В связи с изложенным полагаем правильным исходить из универсальности воли законодателя применительно к п. 4 ст. 346.13 НК РФ, согласно которому утратившие право на применение УСН лица не уплачивают пени и штрафы за несвоевременную уплату ежемесячных платежей в течение того квартала, в котором они перешли на иной режим налогообложения. Данная позиция находит свою поддержку в арбитражной практике, причем по отношению не только к потерявшим право на применение $\mathrm{УCH},{ }^{28}$ но и к бывшим плательщикам ЕСХН, утрачивающим право на льготное обложение страховыми взносами при аналогичных обстоятельствах. ${ }^{29}$

Одновременно хотелось бы отметить, что указанных гарантий освобождения от ответственности и пеней плательщик может быть лишен судом, если действует недобросовестно, в т. ч. применяет УСН, хотя мог и должен был знать об отсутствии у него такого права. ${ }^{30}$

В остальном действуют общие правила освобождения плательщика от штрафных санкций, т. е. при обнаружении по вине плательщика обстоятельств, препятствующих использованию пониженных ставок страховых взносов, в отчетных периодах, следующих за периодом их фактического возникновения (но в любом случае до того, как эти обстоятельства стали известны контролирующему органу), плательщик обязан произвести перерасчет и доплату взносов с первого числа месяца того

\footnotetext{
${ }^{28}$ См. Решение Арбитражного суда Республики Карелия от 13.06.2012 №A26-3387/2012.

29 См. Постановление ФАС Поволжского округа от 04.04.2013 №A72-5620/2012.

${ }^{30}$ См. Постановление ФАС Центрального округа от 14.05.2007 №A64-2122/06-13.
}

отчетного периода, в котором эти преференции были утрачены, а также пеней в соответствии с п. 1 ч. 4 ст. 17 Закона о страховых взносах.

Аналогичным образом решается вопрос о моменте возникновения и прекращения права на применение льготных тарифов страховых взносов плательщиками-предпринимателями, применяющими патентную систему налогообложения и указанными в п. 14 ч. 1 ст. 58 Закона о страховых взносах. Тот факт, что выдача патента по смыслу положений п. п. 2, 5 ст. 346.45, п. 2 ст. 346.49 НК РФ не связывается законодателем с началом какого-либо календарного периода (месяца, квартала, года), не позволяет сделать вывод о возникновении права на применении пониженных тарифов страховых взносов именно с даты выдачи патента, поскольку это противоречило бы положениям п. П. 1, 3 ст. 8, п. 3 ст. 15 Закона о страховых взносах, обязывающим определять облагаемую базу и сумму ежемесячного платежа нарастающим итогом по окончании каждого календарного месяца. Поэтому предприниматель получает право на льготное обложение страховыми взносами с первого числа отчетного периода, в течение которого ему был выдан патент. Прекращается же соответствующее право в день истечения срока действия патента (п. 5 ст. 346.45 НК РФ), а в случае нарушения налогоплательщиком условий применения патента - с начала налогового периода, т. е. фактически со дня выдачи патента (п. 6 ст. 346.45 НК РФ). При этом п. 7 ст. 346.45 НК РФ содержит правило аналогичное п. 4 ст. 346.13 НК РФ, в связи с чем плательщик страховых взносов, утративший право на применение патентной системы налогообложения до окончания срока действия патента, обязан восстановить суммы страховых взносов в размере общеустановленных тарифов, начиная с того отчетного периода, когда было утрачено право на патент, но при этом он не должен 


\section{Налоги и налогообложение - №7(109)• 2013}

платить пени и штрафы за несвоевременную уплату взносов.

Однако право быть отнесенным к льготной категории плательщиков страховых взносов не ограничивается одним только указанием на режим налогообложения. В силу ч. 1.4 ст. 58 Закона о страховых взносах для организаций и предпринимателей, указанных в п. 8 ч. 1 этой же статьи и применяющих УСН, условие об основном виде экономической деятельности считается соблюденным, если доля доходов от реализации продукции и (или) оказанных услуг по данному виду деятельности составляет не менее $70 \%$ в общем объеме доходов. При этом сумма доходов определяется в соответствии со ст. 346.15 НК РФ. Поскольку отчетными периодами для плательщиков единого налога по УСН, признаются квартал, полугодие и 9 месяцев (п. 2 ст. 346.19 НК РФ), а доходы и расходы определяются нарастающим итогом с начала календарного года (п. 5 ст. 346.18 НК РФ), постольку относящийся к данной льготной категории плательщик обязан подтверждать соответствие процентного соотношения доли доходов от реализации товаров (работ услуг), поименованных в п. 8 ч. 1 ст. 58 Закона о страховых взносах, в общем объеме доходов только по итогам года, а не каждого месяца, за который уплачиваются ежемесячные обязательные платежи. И, если доля дохода, полученного от реализации соответствующей продукции (работ, услуг), в каком-либо из месяцев (кварталов) составила менее 70\% месячной (квартальной) выручки, плательщик не будет лишен права на применение пониженных тарифов страховых взносов, если по окончании года доход от такой деятельности составит не менее $70 \%$ от валового дохода. Данный вывод косвенно подтверждается ситуацией, рассмотренной в Письме Минздравсоцразвития РФ от 15.09.2011 №3333-19, при которой организа- ции, выполнившей условие о доле доходов от осуществления основного вида деятельности лишь по итогам 9 месяцев, разъясняется право применить пониженные тарифы страховых взносов с 1 января года с возможностью произвести перерасчет ранее уплаченных в общем порядке взносов путем их возврата или зачета.

В том же порядке должно осуществляться подтверждение права на применение пониженных тарифов страховых взносов сельскохозяйственными товаропроизводителями и плательщиками ECXН (п. п. 1, 2 ч. 1 ст. 58 Закона о страховых взносах), т. е. по итогам налогового периода - календарного года, в пользу чего находится аргументация и в судебной практике. ${ }^{31}$

Более того, согласно позиции некоторых арбитражных судов ${ }^{32}$ несоответствие показателей деятельности организации признакам сельскохозяйственных товаропроизводителей (например, в части объема работ, выполняемых членами сельскохозяйственного кооператива, доли дохода от сбора, переработки, реализации сельхозпродукции) не лишает эту организацию на применение льгот. Мотивировка данному выводу следующая: поскольку и сельскохозяйственный кооператив, и сельскохозяйственный товаропроизводитель есть организационно-правовая форма, предусмотренная ст. 1 Федерального закона «О сельскохозяйственной кооперации» от 08.12.1995 №193-Ф3, ${ }^{33}$ с наличием которой налоговое законодательство связывает право на уплату ЕСХH, а законодательство о страховых взносах - право на применение пониженных тарифов, постольку юридическое лицо признается правомочным применять соответствующую льготу до тех

\footnotetext{
${ }^{31}$ См. Постановление ФАС Центрального округа от 03.09.2009 №A64-6882/08-27.

${ }^{32} \mathrm{CM}$. Постановление Тринадцатого арбитражного апелляционного суда от 23.01.2007 №A42-4145/2006.

${ }^{33}$ С3 РФ. - 11.12.1995. - №50. - Ст. 4870.
} 
пор, пока его организационно-правовая форма зарегистрирована в установленном порядке. Налоговым органам как органам регистрирующим предоставлено право обеспечивать методами административного воздействия соблюдение порядка регистрации юридических лиц. Поэтому вплоть до внесения изменений в части записи об организационно-правовой форме в ЕГРЮЛ, в т. ч. на основании ст. 57 ГК РФ, организация сохраняет право применять льготные тарифы страховых взносов.

При всем изложенном вызывает критику положение ч. 1.4 ст. 58 Закона о страховых взносах, согласно которому если основной вид экономической деятельности по итогам отчетного (расчетного) периода не соответствует заявленному, организация или предприниматель лишаются права применять пониженные тарифы страховых взносов с начала отчетного (расчетного) периода, в котором допущено такое несоответствие. Очевидно, что на протяжении отдельно взятого отчетного периода в силу сезонности или иных объективных причин плательщик может осуществлять деятельность вида, не заявленного в качестве основного, либо не осуществлять никакой деятельности. И подобные обстоятельства сами по себе не являются препятствием к сохранению по итогам года должной пропорции доходов от основного и прочих видов экономической деятельности, в т. ч. когда плательщиком была совершена хотя бы одна крупная сделка на сумму, равную 70\% его общегодового дохода. В этом смысле можно сказать, что ч. 1.4 ст. 58 Закона о страховых взносах не увязывается с системой действующего правового регулирования, выпадает из нее и, следовательно, нуждается в серьезной корректировке.

По этой же причине нельзя согласиться с мнениями авторов, делающих вывод об отсутствии у организации права применять пониженные тарифы страховых взносов в случае, если в отчетном периоде она вообще не имела доходов. ${ }^{34} \mathrm{C}$ подобной трактовкой не соглашаются и арбитражные суды. ${ }^{35}$ Констатировать наличие и размер доходов от льготируемого вида деятельности в относительном исчислении к валовому доходу возможно только по итогам расчетного периода, т. е. календарного года. Кроме того, буквальное прочтение ч. 1.4 ст. 58 Закона о страховых взносах показывает, что законодатель придал правовое значение не самому факту получения дохода, а арифметической пропорции суммового выражения дохода от основного вида деятельности к общей сумме поступлений (выручки).

Немаловажным представляется и тот фактор, что право лиц, применяющих УСН, на исчисление страховых взносов по пониженным тарифам не поставлено законодателем в зависимость от того, получены ли необходимые $70 \%$ дохода в рамках деятельности, облагаемой по УСН, либо подпадающей под иной режим налогообложения. Поэтому в случаях, когда в отношении какого-либо из основных видов экономической деятельности, указанных в п. 8 ч. 1 ст. 58 Закона о страховых взносах, местными органами власти введен ЕНВД, ${ }^{36}$ плательщики сохраняют право на льготные условия обложения страховыми взносами. Главное, чтобы наряду с уплатой ЕНВД применялась УСН и доля дохода от вида деятельности, пусть и облагаемого ЕНВД, но заявленного в качестве основного, составляла не менее $70 \%$ в общем объеме

\footnotetext{
${ }^{34}$ См. Юсупов К. И. Вопрос и ответ // Аптека: бухгалтерский учет и налогообложение. - 2012. - №12. С. 34. ${ }^{35}$ См. Определение ВАС РФ от 24.08.2010 №ВАС$11485 / 10$, Постановление Второго арбитражного апелляционного суда от 10.10.2012 №А82-2229/2012.

${ }^{36}$ Например, п. 3 ст. 1 Закона Санкт-Петербурга от 17.06.2003 №299-35 деятельность по ремонту и техническому обслуживанию автотранспортных средств (пп. «ч» П. 8 ч. 1 ст. 58 Федерального закона от 24.07.2009 №212-Ф3) переведена на уплату ЕНВД.
} 


\section{Налоги и налогообложение - №7(109)• 2013}

доходов. Противоположная позиция Минфина РФ, изложенная в Письме от 24.06.2011 №03-1106/2/97, а также резонирующие с ней мнения отдельных специалистов, ${ }^{37}$ полагаем, основаны на неправильном и несистемном толковании норм действующего законодательства.

Также не имеет правового значения удельная доля работников, задействованных в льготируемом виде экономической деятельности. По пониженным тарифам облагаются выплаты и вознаграждения любого рода всем без исключения физическим лицам, о чем сказано в Письме Минздравсоцразвития РФ от 14.06.2011 №2011-19. ${ }^{38}$ В этом заключается отличие применяющих УСН лиц от организаций, к примеру, аптечной отрасли, так же имеющих право на уплату взносов по пониженным тарифам, но для которых льготируются только выплаты работникам, задействованным непосредственно в профильной фармацевтической деятельности (п. 10 ч. 1 ст. 58 Закона о страховых взносах).

Правовая политика российского государства в области социально-страхового законодательства на этапе реформирования последнего, характеризующаяся принципиальной трансформацией объекта обложения, не позволяет обойти стороной обнаруживающиеся в связи с этим и достаточно ощутимые с экономической точки зрения изъяны.

Так, каждый индивидуальный предприниматель, нотариус или адвокат признается застрахованным и потому обязан уплачивать страховые взносы за себя в течение всего периода страхования - с момента государственной регистрации в качестве индивидуального предпринимателя и до регистрации прекращения им деятельности в

${ }^{37}$ См. Колосова И. Ю. Контролеры о страховых взносах при спецрежимах // Оплата труда: бухгалтерский учет и налогообложение. - 2011. - №9. С. 51.

${ }^{38}$ Официальные документы. - 2011. - №24. таком качестве. При этом в отличие от ранее действовавшей гл. 24 НК РФ пришедшее на смену законодательство о страховых взносах не предусматривает возможности уменьшения доходов предпринимателей и иных лиц, занимающихся частной практикой, на сумму расходов, связанных с их извлечением.

Для самостоятельно обеспечивающих себя работой лиц, ранее уплачивавших ЕСН с суммы доходов, полученных от предпринимательской или иной профессиональной деятельности, уменьшенных на величину соответствующих расходов (п. 3 ст. 237 НК РФ), объект обложения фактически был заменен на величину вмененного дохода, приравненного к минимальному размеру оплату труда (п. п. 1.1, 1.2 ст. 14 Закона о страховых взносах), который те в любом случае обязаны перечислить в государственные внебюджетные фонды. Размер реально полученного дохода (выручки, прибыли), равно как и сам факт осуществления или неосуществления предпринимательской деятельности в течение расчетного периода утратили правовое значение - плательщик несет обязанность перечислить во внебюджетные фонда страховые взносы, даже если не имел дохода, получил убыток, или фактически приостановил (прекратил) осуществлять приносящую доход деятельность. Факт осуществления или неосуществления предпринимательской или иной профессиональной деятельности физическим лицом, равно как и ее результат-получение либо неполучение дохода (по любым причинам), охватывается понятием предпринимательского риска и не влияют на изменение или прекращение обязанности по уплате страховых взносов. ${ }^{39}$

Поправки, введенные в действие ст. 6 Федерального закона от 03.12.2012 №243-Ф30 в

\footnotetext{
${ }^{39}$ См. Постановление Одиннадцатого арбитражного апелляционного суда от 15.12.2010 №A72-6449/2010. ${ }^{40}$ СЗ РФ. - 10.12.2012. - №50 (ч. 5). - Ст. 6966.
} 
части установления необлагаемых страховыми взносами периодов, коснулись не всех, а лишь некоторых из периодов, поименованных в п. 1 ст. 11 Федерального закона «О трудовых пенсиях в РФ» от 17.12.2001 №173-Ф3.41 В число таких исключений попали случаи призыва лица на военную службу, осуществления ухода за ребенком до достижения им возраста 1,5 лет, инвалидом I группы, ребенком-инвалидом, престарелым лицом, достигшим возраста 80 лет, переезда супругов военнослужащих или сотрудников дипломатических служб в отдаленную местность или за границу РФ (ч. 6 ст. 14 Закона о страховых взносах).

В то же время, ограниченный перечень оснований для освобождения самозанятого населения от уплаты страховых взносов не учитывает периоды временной нетрудоспособности, беременности и родов, ухода за ребенком до достижения им 3-летнего возраста, отбывания наказания, сопряженного с невозможностью осуществления деятельности, а также особенностей некоторых производств (работ, услуг), носящих сезонный характер, и многих иных обстоятельств, не зависящих от воли плательщиков страховых взносов. ${ }^{42}$ В любой из вышеперечисленных ситуаций единственным основанием прекращения обязанности физического лица, самостоятельно обеспечивающего себя работой, по уплате страховых взносов становится регистрация прекращения деятельности в качестве индивидуального предпринимателя, а равно освобождение от должности нотариуca, прекращение статуса адвоката. Очевидно, это не способствует стабилизации делового климата и уж тем более укреплению класса малого предпринимательства. Наиболее подверженными увеличению фискальной нагруз-

${ }^{41}$ С3 РФ. - 24.12.2001. - №52 (ч. 1). - СТ. 4920.

${ }^{42} \mathrm{CM}$. Постановление Тринадцатого арбитражного апелляционного суда от 27.05.2011 №A56-40431/2010. ки при этом стали предприниматели, главы крестьянских фермерских хозяйств, адвокаты и нотариусы, в т. ч. являющиеся инвалидами, доходы которых с 2010 г. стали облагаться наравне с доходами лиц, обладающих полной трудоспособностью и потому имеющих объективно больше возможностей для реализации своих профессиональных навыков.

Подобное правовое регулирование вряд ли можно рассматривать как отвечающее принципу социальной справедливости. К примеру, по смыслу взаимосвязанных положений п. 2 ст. 44, п. 2.3 ст. 346.26 , п. 3 ст. 346.28 НК РФ обязанность уплаты ЕНВД возникает не ранее момента начала фактического осуществления налогооблагаемой деятельности и прекращается с подачей заявления о прекращении предпринимательской деятельности, подлежащей обложению единым налогом. Поэтому с учетом принципа универсальности воли законодателя представляется необходимым освободить от обложения страховыми взносами индивидуальных предпринимателей и иных самозанятых лиц на периоды, когда ими фактически не осуществлялась приносящая доход деятельность. В противном случае возникает ситуация, при которой отсутствует экономическое основание обложения взносами, т. е. возложение на лицо обязанности уплаты страхового взноса как публично установленного платежа не будет обеспечено каким-либо источником его финансирования (выручкой, доходом, прибылью), что недопустимо.

Достоверность приведенного вывода подтверждается позицией Конституционного Суда РФ, выраженной им в Определении от 12.05.2005 №182-O.43 Им, в частности, были истолкованы ранее действовавшие правовые нормы, определявшие порядок уплаты стра-

${ }^{43}$ C3 РФ. - 11.07.2005. - №28. - Ст. 2905. 


\section{Налоги и налогообложение - №7(109)• 2013}

ховых взносов на обязательное пенсионное страхование в виде фиксированного платежа, как не предполагающие взимание с индивидуальных предпринимателей страховых взносов в бюджет ПФР за периоды, в течение которых предпринимательская деятельность ими не осуществлялась.

Аналогичная трактовка, в дальнейшем поддержанная арбитражной практикой на местах, ${ }^{44}$ была дана Высшим Арбитражным Судом РФ в п. 3 Информационного письма от 11.04.2006 №107, ${ }^{45}$ согласно которому индивидуальные предприниматели не уплачивают страховые взносы в виде фиксированного платежа в случае неосуществления ими деятельности в периоды, указанные в п. 1 ст. 11 Федерального закона «О трудовых пенсиях в РФ». Поскольку реформа системы социального налогообложения 2010 г. не повлекла за собой качественного изменения социально-экономической и правовой природы страховых взносов в государственные внебюджетные фонды (переход от налогового к страховому механизму финансирования государственных внебюджетных фондов по сути является изменением экономического рода), ${ }^{46}$ представляется, что ранее сформированная в арбитражной практике правовая позиция должна сохранять свою актуальность.

Ввиду изложенного предлагается дополнить ч. 6 ст. 14 Закона о страховых взносах абзацем следующего содержания: «Плательщики страховых взносов, указанные в пункте 2 части 1 статьи 5 настоящего

\footnotetext{
${ }^{44}$ См. Решение Арбитражного суда Республики Карелия от 27.05.2011 №A26-1333/2011.

${ }^{45}$ Вестник ВАС РФ. - 2006. - №7.

${ }^{46}$ См. Перемышленникова О. Н. К вопросу о правовой природе страховых взносов в государственные социальные внебюджетные фонды // Финансовое право. - 2012. - №7. С. 39-40.
}

Федерального закона, не исчисляют и не уплачивают страховые взносы на обязательное пенсионное страхование и обязательное медицинское страхование в фиксированных размерах также в иные периоды, в течение которых предпринимательская или иная профессиональная деятельность ими не осуществлялась, при условии представления подтверждающих это обстоятельство документов».

Справедливости ради стоит отметить, что действующий порядок исчисления и уплаты страховых взносов также нуждается в укреплении защиты от недобросовестных действий плательщиков, в т. ч. относящихся к льготным категориям, и прежде всего, в условиях многократных и ничем не сдерживаемых регистраций фактов, связанных с прекращением и созданием новых юридических лиц.

В частности, особенности сроков уплаты страховых взносов и представления отчетности установлены для плательщиков, момент прекращения деятельности которых не совпадает с окончанием расчетного (отчетного) периода. Согласно ч. 15 ст. 15 Закона о страховых взносах при ликвидации организации или прекращении деятельности физического лица в статусе индивидуального предпринимателя такие лица обязаны сдать отчетность по начисленным и уплаченным страховым взносам перед подачей соответствующего заявления. При этом разница между суммой страховых взносов, подлежащей уплате на основании этого расчета, и суммами взносов, уплаченными с начала расчетного периода, подлежит либо доплате в течение 15-ти календарных дней со дня подачи расчета, либо возврату плательщику. ${ }^{47}$

Примечательно, что законодательство о страховых взносах обходит стороной во-

\footnotetext{
${ }^{47} \mathrm{C}$. Решение Моршанского районного суда Тамбовской области от 08.02.2011 №2-156/11.
} 
прос об обязанности ликвидируемой организации или прекращающего деятельность предпринимателя уплатить взносы с сумм выплат, произведенных ими в период со дня представления последнего расчета и до дня государственной регистрации ликвидации или прекращения деятельности в качестве индивидуального предпринимателя.

Исходя из буквального толкования ч. 15 ст. 15 Закона о страховых взносах, на обозначенный вопрос надлежит дать отрицательный ответ, поскольку обязанность уплатить страховые взносы в данном случае ограничена той суммой, которая была указана плательщиком в расчете, предоставленном им до дня подачи пакета документов на государственную регистрацию ликвидации организации (прекращения деятельности индивидуального предпринимателя). По понятным причинам выплаты физическим лицам, произведенные после представления расчета, не будут учтены при уплате страховых взносов на основании такого расчета.

Кроме того, содержание взаимосвязанных положений ч. 15 ст. 15 Закона о страховых взносах и п. 1 ст. 8 Федерального закона «О государственной регистрации юридических лиц и индивидуальных предпринимателей» от 08.08.2001 №129-Ф348 позволяет сделать вывод, что момент окончания 15-дневного срока исполнения обязанности по уплате страховых взносов ликвидируемой организацией может наступить после внесения записи о ликвидации в ЕГРЮЛ, для чего установлен менее продолжительный 5-дневный срок с момента подачи в налоговый орган соответствующего заявления. Этим пользуются недобросовестные организации, не имевшие права на льготы, но неправомерно платившие в течение расчетного

${ }^{48}$ СЗ РФ. - 13.08.2001. - №33 (ч. 1). - Ст. 3431. периода страховые взносы по пониженным тарифам, а то и вовсе не платившие их, которые инициируют свою ликвидацию в добровольном порядке и завершают ее, не дожидаясь истечения срока исполнения обязанности по погашению образовавшейся недоимки.

Очевидно, что к организации, утратившей всякую правоспособность ввиду завершенной ликвидации, не могут быть предъявлены требования об исполнении каких бы то ни было обязательств перед государственными внебюджетными фондами. При этом даже на момент подачи заявления о государственной регистрации организации в связи с ее ликвидацией, как правило, уже завершены все расчеты с кредиторами и имущество, за счет которого может быть погашена задолженность перед государством, попросту отсутствует. При таком правовом регулировании внебюджетные фонды терпят убытки, для покрытия которых необходимо изыскивать иные нецелевые источники государственного софинансирования.

В свете изложенного целесообразно внести изменения в п. 15 ст. 15 Закона о страховых взносах, дополнив его обязанностью плательщиков страховых взносов, указанных в пП. «а» и «б» п. 1 ч. 1 ст. 5 Закона о страховых взносах, уплатить разницу между суммой страховых взносов, подлежащей уплате на основании расчета, и суммами взносов, уплаченными с начала расчетного периода, в тот же срок, который установлен данной нормой для представления расчета по начисленным и уплаченным страховым взносам.

В заключение хотелось бы отметить, что само по себе наличие системы льготирования в законодательстве о страховых взносах, определяющем в совокупности с налоговым законодательством степень фискальной нагрузки на субъектов хозяйствования, можно рассматривать как исключительно позитивный фактор. Пониженные тарифы страховых 


\section{Налоги и налогообложение - №7(109)• 2013}

взносов посредством снижения финансовой нагрузки на бизнес призваны, с одной стороны, пробудить деловую активность в более востребованных на данный момент высокотехнологичных кластерах российской экономки, а с другой, не оставить без внимания те отрасли хозяйствования, которые в силу их малоразвитости или невысокой доходности нуждаются в дополнительной государственной поддержке. Однако для эффективного претворения в жизнь указанных благих целей крайне важно устранить имеющиеся противоречия и недостатки законодательного и правоприменительного толка, в значительной степени затрудняющие реализацию поставленных задач.

\section{Библиография:}

1. Кирилова О. Е. Страховые взносы: изменения и нерешенные вопросы //Налоговая политика и практика. - 2011. - №4. - С. 52-61.

2. Климова М. А. Единый социальный налог и взносы на обязательное пенсионное страхование // Экономико-правовой бюллетень.-2008.-№11.-160 с.

3. Колосова И. Ю. Контролеры о страховых взносах при спецрежимах // Оплата труда: бухгалтерский учет и налогообложение. 2011.-№9.-С. 44-54.

4. Кроплис В. Ю. Некоторые правовые аспекты соотношения норм налогового и трудового законодательства при уплате единого социального налога // Арбитражные споры. - 2007. - № 4. - С. 90-100.

5. Морозова И. С. Теория правовых льгот: Автореф. дисс. ... докт. юрид. наук. Саратов: Саратовская государственная академия права, 2007.-47 с.

6. Нестеров С. Е. Начисляем страховые взносы: разъясняют специалисты ФСС //
Оплата труда: бухгалтерский учет и налогообложение. - 2012. - №2. - С. 45-58.

7. Перемышленникова О. Н. К вопросу о правовой природе страховых взносов в государственные социальные внебюджетные фонды // Финансовое право. - 2012. - №7. - С. 36-40.

8. Петров А. В. Налоговая экономия: реальные решения / А. В. Петров. - М.: Бератор Паблишинг, 2009.-300 с.

9. Шилова Л. А. Если общественная организация инвалидов утратила право на льготу по ЕСН // Российский налоговый курьер.2009.-№12.-С. 72-80.

10. Юсупов К. И. Вопрос и ответ // Аптека: бухгалтерский учет и налогообложение.2012.-№12.-С. 34

\section{References (transliteration):}

1. Kirilova O. E. Strahovye vznosy: izmeneniya i nereshennye voprosy //Nalogovaya politika i praktika.-2011.-№4.-S. 52-61.

2. Klimova M. A. Edinyy social'nyy nalog i vznosy na obyazatel'noe pensionnoe strahovanie // Ekonomiko-pravovoy byulleten'.-2008.-№11.-160 s.

3. Kolosova I. Yu. Kontrolery o strahovyh vznosah pri specrezhimah // Oplata truda: buhgalterskiy uchet i nalogooblozhenie. 2011.-№9.-S. 44-54.

4. Kroplis V. Yu. Nekotorye pravovye aspekty sootnosheniya norm nalogovogo i trudovogo zakonodatel'stva pri uplate edinogo social'nogo naloga // Arbitrazhnye spory. 2007. - № 4. - S. 90-100.

5. Morozova I. S. Teoriya pravovyh l'got: Avtoref. diss. ... dokt. yurid. nauk. Saratov: Saratovskaya gosudarstvennaya akademiya prava, 2007.-47 s. 
DOI: $10.7256 / 1812-8688.2013 .7 .9355$

При цитировании этой статьи сноска на doi обязательна

\section{Правовое регулирование налоговых отношений}

6. Nesterov S. E. Nachislyaem strahovye vznosy: raz'yasnyayut specialisty FSS // Oplata truda: buhgalterskiy uchet i nalogooblozhenie. 2012. - №2. - S. 45-58.

7. Peremyshlennikova O. N. K voprosu o pravovoy prirode strahovyh vznosov v gosudarstvennye social'nye vnebyudzhetnye fondy // Finansovoe pravo. - 2012. - №7. - S. 36-40.
8. Petrov A. V. Nalogovaya ekonomiya: real'nye resheniya / A. V. Petrov. - M.: Berator Pablishing, 2009. - 300 s.

9. Shilova L. A. Esli obschestvennaya organizaciya invalidov utratila pravo na l'gotu po ESN // Rossiyskiy nalogovyy kur'er. - 2009. - №12. - S. 72-80.

10. Yusupov K. I. Vopros i otvet // Apteka: buhgalterskiy uchet i nalogooblozhenie. - 2012. - №12. - S. 34 